\title{
SNOW DEPTH AND SNOW DENSITY AT RESOLUTE, NORTHWEST TERRITORIES
}

\author{
By Richmond W. Longley \\ (University of Alberta)
}

\begin{abstract}
Observations of the snow depth at 2 I sites at Resolute were made twice weekly during the winter of 1957-58. As a result of these observations, and of other observations on snow made for the National Research Council, it is shown that the snow depth and the water content of the snow did not continue to increase during the winter as the snow fell. Rather the strong winds eroded the snow surface and the increase in depth was irregular and relatively slow. Furthermore, the observations on the density of the snow cover lead to the conclusion that attempts to measure the density in similar regions with an accuracy greater than $\pm 0.05 \mathrm{~g} . \mathrm{cm} \cdot .^{-3}$ are not warranted.
\end{abstract}

Résumé. Pendant l'hiver 1957-58 on a pris des mesures deux fois par semaine de l'épaisseur de la neige à 2 I endroits à Resolute. Par suite de ces observations et d'autres observations de la neige faites pour le Conseil National de Recherches, on a pu montrer que l'épaisseur et la valeur en eau de la neige n'allaient pas croissant pendant l'hiver au fur et à mesure des précipitations. Il semble plutôt que des vents forts ont érodé la surface de la neige de sorte que l'épaisseur s'augmentait de manière irrégulière et relativement lente. De plus, des observations de la densité de la couche neigeuse laissent conclure qu'aucun essai de mesure de la densité dans des régions analogues à un degré de précision supérieur à $\pm 0,5 \mathrm{~g} \mathrm{~cm}^{-3}$ ne puisse être valable.

Zusammenfassung. Beobachtungen der Schneetiefe wurden zweimal wöchentlich im Winter 1957-58 an 21 Stellen bei Resolute ausgeführt. Diese ergänzt durch andere für den National Research Council durchgeführten Beobachtungen zeigen, dass die Schneetiefe und der Wassergehalt des Schnees mit dem im Winter fallenden Schnee nicht ständigzunahmen. Die starken Winde erodierten im Gegenteil die Schneeoberfläche, und infolgedessen ging die Tiefenzunahme unregelmässig und relativ langsam vor sich. Ferner lässt sich aus Beobachtungen über die Dichte der Schneedecke schliessen, dass Versuche, die Dichte in ähnlichen Regionen mit einer Genauigkeit grösser als $\pm 0,05 \mathrm{~g} \mathrm{~cm}^{-3}$ sich nicht rechtfertigen lassen.

\section{Observing Program}

Since the winter of $1949-50$, the observing program at Resolute, Northwest Territories (lat. $75^{\circ}$ N., long. $95^{\circ}$ W.), has included careful observations on the characteristics of the snow lying on the ground. These observations are taken as part of the program to study the snow cover over Canada, organized by the National Research Council. During the winters of $195^{6-57}$ and $1957-5^{8}$ these observations were made by the author or under his direction.

For the winter $1957-58$, plans were made to obtain one extra set of data to add to the information desired by the National Research Council. Twenty-one stakes marked in inches were placed in a straight line at intervals of $40 \mathrm{yd} .\left(36.5^{8} \mathrm{~m}\right.$.) so that snow depths could always be obtained at the same locations. Observations were taken usually twice weekly. The official snow depth for the station was the mean value as obtained from the 2 I stakes. The location of the line of stakes was from the east shore of a lake 0.25 mile $(0.40 \mathrm{~km}$.) east of the camp site, eastward over the rolling country formed by raised marine beaches, with the last four stakes on the lower slopes of a hill which rises to about $600 \mathrm{ft}$. (I82.9 m.) above m.s.l., 0.75 mile ( $1 \cdot 2 \mathrm{I} \mathrm{km}$.) east of the camp.

No evidence can be produced to show that the location was representative of the island as a whole. Even among these $2 \mathrm{I}$ points there were wide differences. Location $2 \mathrm{I}$ had no snow all winter, while Site $20,40 \mathrm{yd}$. $(36 \cdot 58 \mathrm{~m}$.) distant, had I $5 \mathrm{in}$. (38.10 $\mathrm{cm}$.) or more after 18 October. The maximum single depth observed was at the edge of the lake with 29 in. $(73.66 \mathrm{~cm}$.) on 18 May. The same date recorded the maximum mean depth for the winter of $9 \cdot 2$ in. $(23 \cdot 37 \mathrm{~cm}$.). The standard deviation of the observations on 18 May was $6 \cdot 2 \mathrm{in}$. $(15.75 \mathrm{~cm}$.), giving a standard error of the mean of $1 \cdot 4 \mathrm{in} .(3 \cdot 56 \mathrm{~cm}$.). On the wind-swept island on which Resolute is located, many locations were never covered with more than 3 in. $(7 \cdot 62 \mathrm{~cm}$.) of snow, while in protected locations depths of $20 \mathrm{ft}$. (6. I0 m.) were common and roo-ft. $(30.48 \mathrm{~m}$.) ravines filled to the top to form snow bridges. Although the mean 
depth may not have been representative of the island, the observed values were comparable from one observation to the next, and as such give useful information.

At almost every time of observation, the mean density of the snow on the ground was taken. The site for the sample was usually within $100 \mathrm{ft}$. $(30.48 \mathrm{~m}$.) of Site 2 , at which point the snow depth was close to the mean value. The density was obtained by taking a vertical sample of the snow by means of a hollow cylinder and weighing it, as directed by the National Research Council.

\section{Mean Snow Depth}

The results of the observations during the winter are given in Figure I. Five separate curves are shown. Curve (a) gives the snow depth as obtained from the 2 I stakes during the winter of $1957-5^{8}$. Curve (b) gives the water content of the snow, obtained from the density and the snow depth. Curve (c) gives the accumulated snowfall after I September as reported in the synoptic observations. Curves (d) and (e) are for comparison purposes. Curve (d) gives the mean accumulated snowfall, computed first for three io-day periods of each month, and then summed. Data used extended from October 1947 until June 1958. Curve (e) gives the mean snow depth, using available data, computed for the tenth, twentieth and last day of each month.

Curves (a), (b) and (c) refer to the same winter's snow. In comparing curves (a) and (c), one notes that both rose at first until I 3 October at which time the snow depth was $7 \cdot 3$ in. $\left(18.54 \mathrm{~cm}\right.$.) and the accumulated snowfall was io in. $\left(25.40 \mathrm{~cm}\right.$.). Between $\mathrm{I}_{3}$ October and 30 April the snow depth remained between 6 and 8 in. ( 15.24 and $20 \cdot 32 \mathrm{~cm}$.), even though the accumulated snowfall rose from 10 to 22 in. $(25.40$ to $55.88 \mathrm{~cm}$.). The snowfall of 2 in. $(5.08 \mathrm{~cm}$.) in May was reflected in a temporary increase of $\mathrm{I}$ in. $(2.54 \mathrm{~cm}$.) in the depth of the snow on the ground.

\section{Density and Water Content}

One cannot explain the shape of the snow depth curve by a change in the density. After the total water content rose to approximately $2 \mathrm{in} .(5.08 \mathrm{~cm}$.) on 20 October, it showed no sustained trend away from this value until 30 April. The additional snow apparently did not remain in the vicinity of the stakes after 20 October. Some of the irregularities of curve (b) can be explained by the changes in curve (a), but many cannot.

With the depth of snow approximately constant during the winter months, it would seem that the total water content of the snow should change only gradually with the settling of the snow. If so, then the irregularities in curve (b) come from errors in the computed densities. That the density varied was discovered when, on several occasions, two samples were taken from points less than $100 \mathrm{yd}$. (9I.44 m.) apart. Records of some of these occasions are given in Table I.

Table I. Snow Densities (g. cm. ${ }^{-3}$ ) at Two Locations wtthin ioo yd. $\left(91^{\circ} \cdot 44\right.$ m.)

\begin{tabular}{lcc}
\multicolumn{1}{c}{ Date } & Sample I & Sample 2 \\
27 November & 0.25 & 0.29 \\
15 December & 0.28 & 0.38 \\
18 December & 0.27 & 0.29 \\
16 January & 0.27 & 0.35 \\
15 February & 0.26 & 0.31 \\
18 February & 0.25 & 0.35 \\
26 February & 0.32 & 0.37 \\
26 March & 0.28 & 0.30 \\
24 April & 0.27 & 0.29
\end{tabular}


Weather and Snow Depth

A study of the weather as it was related to the changes of the snow depth showed that in general high winds removed the snow, but the relationship was not clear cut. During a bad storm from 4 to 7 January, the mean depth dropped $1.8 \mathrm{in} .(4.57 \mathrm{~cm}$.). Between $\mathrm{I} 4$ and I 8 May there was a strong east wind that carried snow into some of the hollows along the line of stakes. Most of the stakes showed slight drops in the depth of the snow. Because each of three stakes registered increases of $6 \mathrm{in}$. ( $15.24 \mathrm{~cm}$.) snow or more, the mean depth rose 0.6 in. $\left(\mathrm{I} \cdot 5^{2} \mathrm{~cm}\right.$.). Later in the month, $2 \mathrm{I}$ to 24 May, another storm removed $0.9 \mathrm{in} .(2 \cdot 20$ $\mathrm{cm}$.) of soft snow which had fallen during the month. The average depth at the location of the 2 I stakes would appear to qualify as a representative depth.

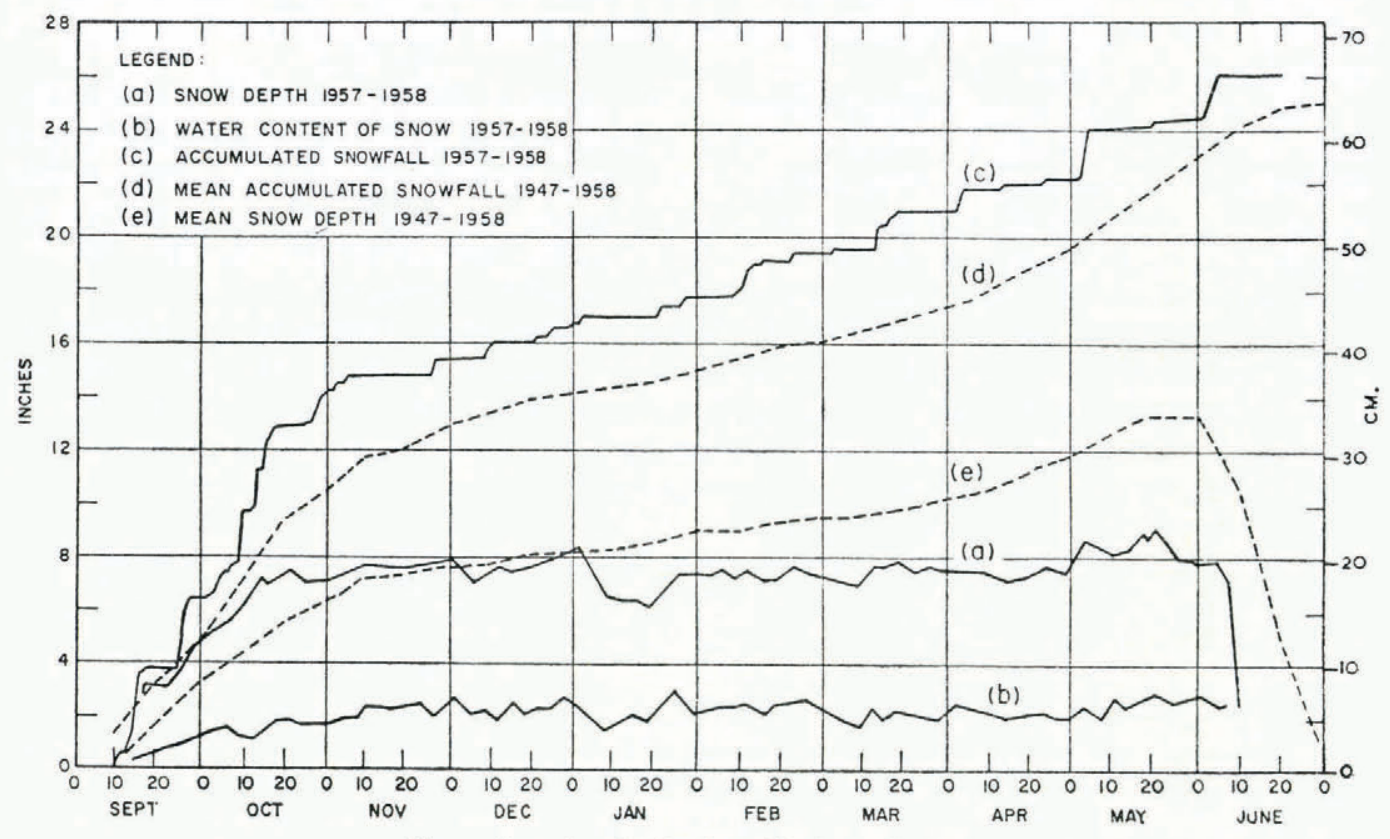

Fig. I. Snow data for Resolute, Northuest Ferritories

As a corollary to this conclusion, the mean water content of the snow cover should represent the accumulation of snow. In southern latitudes, the melting and evaporation as a result of heat coming from the earth or during periods of thaws would decrease the mean snow cover. At Resolute there is no heat from the ground sufficient to melt snow after I September. Also, heat from the sun or air will not melt snow until the sun is high enough in the spring to supply heat to the snow surface, that is until I May at the earliest. Some deposit as frost would increase the snow cover slightly during the winter period. Yet, according to the data collected, the snow depth on 30 April was only $0.5 \mathrm{in}$. $(1 \cdot 27 \mathrm{~cm}$.) more than on I 8 October, and the water content was almost exactly the same. During this period 9 in. $(22 \cdot 86 \mathrm{~cm}$.) of snow was recorded as falling.

One source of error in assuming that the "mean depth" of snow represents the average snow cover is the effect of the wind in filling ravines and protected areas. These ravines, some roo ft. $(30.48 \mathrm{~m}$.) or more in depth, gradually fill during the winter season as the wind carries the snow from the level areas. Two extra stakes located on the level area at the top of 
the hill, and about $500 \mathrm{ft}$. $\left(15^{2} \cdot 40 \mathrm{~m}\right.$.) above the camp site, were observed at irregular intervals. These never showed more than $2 \mathrm{in} .(5.08 \mathrm{~cm}$.) of snow in their vicinity, and most of the winter the ground about them was bare. It is apparent from the observations that in the Arctic the depth of snow at any spot after the initial increase in the early winter is a function of the contours of the underlying surface in the vicinity and also of the direction of the last strong eroding wind. Except in protected areas, the accumulated snowfall does not affect greatly the snow cover.

Other factors in southern latitudes enter to make conclusions about the choice of a representative site easier than in the Arctic. The snow gradually changes its density and settles as it lies on the ground. Also, warmer temperatures, wind and sun all tend to form a crust on the top of the snow to keep it in place. The wind does not usually have so good an opportunity to sweep over the snow and cause erosion. Yet in spite of these factors, it may be that the effect of local topography is more significant than usually considered in the choice of a representative location.

The storm of $2 \mathrm{I}$ to 25 January illustrates the problem of measurement in the Arctic. Meteorologically, the situation was such that a moderate snowfall was probable, and over the period the snow depth increased $0 \cdot 9 \mathrm{in} .(2 \cdot 29 \mathrm{~cm}$.). Yet the recorded snowfall was only 0.4 in. ( $1 \cdot 02 \mathrm{~cm}$.). With very high winds, maximum over $60 \mathrm{~m} . \mathrm{p} . \mathrm{h} .(26 \cdot 8 \mathrm{~m} . / \mathrm{sec}$.$) , the air$ was filled with snow and there was no way of determining the amount that fell from the sky. This source of error is well recognized but there is no solution apparent.

A comparison of curves (a) and (e) in Figure $\mathrm{I}$ is interesting. The similarity of curves (c) and (d) shows that in snowfall the winter of $1957-5^{8}$ was not far from average. Yet the average of recorded depths for all seasons (curve (e)) rose steadily from $6 \mathrm{in}$. (I5.24 cm.) on 25 October to 13.4 in. $\left(34^{\circ} 04 \mathrm{~cm}\right.$.) on 15 May. In contrast, during the winter $1957-5^{8}$ there was a rise of only $2 \mathrm{in.}(5.08 \mathrm{~cm}$.) in the same period, I in. $(2.54 \mathrm{~cm}$.) before 30 April and I in. $(2.54 \mathrm{~cm})$. after.

No simple explanation of this difference is apparent. It is possible that the location of the stakes was on a less representative site than those chosen in previous years; but visual observations during the two seasons, $195^{6-58}$, lead the author to doubt whether the depth of the snow continues to rise except in places where it drifts, such as around buildings and in ravines. Such a conclusion fails to answer the question of where the snow goes durirg the winter. Unless the observers of previous years were careful, they may have been tempted to measure the snow depth at locations where the effects of the buildings were not entirely eliminated. During one period of observations in the past, when snow depths were recorded to one-tenth of an inch $(0.25 \mathrm{~cm}$.), there was an apparent tendency to increase the snow depth by an amount equal to the snowfall. The past records seldom showed any recognition that a strong wind might remove some of the snow. The difference between curves (a) and (e) is brought out by considering their ratios to curves (c) and (d) respectively. The ratio of mean snow depth to the mean snowfall remains between 0.55 and 0.6 I from 20 October until 20 May. For the $1957-5^{8}$ season the ratio was 0.60 on 20 October, then between 0.49 and $0.5^{1}$ until 3I December. For the period after I January the ratio lay between 0.35 and 0.43 .

The difference between curves (a) and (e) in Figure $I$ is related to the problem of choosing a representative site for measurement. The purpose of a measurement of snow depth is to obtain a measure of the mean depth over the surrounding area. The standard method of making such a measurement is to take a number of measurements over a wide area and obtain an average from these. The observations taken at Resolute show that the mean is not necessarily representative.

One question whose answer was sought remains unanswered by the snow depth observations. During May I 957 there were a number of days with light winds, clear skies and subfreezing temperatures. Running water showed that the sun was melting some of the snow even though the air temperature was below $32^{\circ} \mathrm{F}$. ( $0^{\circ} \mathrm{C}$. $)$. During May $195^{8}$ there were 
only two days when conditions were closely similar. On both days, 18 and 26 May, the snow depth dropped 0.25 in. ( $1 \cdot 78 \mathrm{~cm}$.). It would be interesting to know how much snow does melt under ideal conditions. On 7 June the temperature first rose above $32^{\circ} \mathrm{F}$. $\left(0^{\circ} \mathrm{C}\right.$. $)$. In three days the depth dropped from $7 \cdot 3$ in. $(18.54 \mathrm{~cm}$.) to $2 \cdot 6 \mathrm{in}$. $(6 \cdot 60 \mathrm{~cm}$.) with snow remaining only around 7 stakes where it had been deepest.

\section{Snow SAmpling for Density}

Table I and the related discussion suggested that the mean snow density could not be considered too accurate. Further observations in March, April and May gave additional information.

As noted above, the snow densities were computed by means of a hollow cylinder inserted perpendicular to the snow surface, and the snow sample measured and weighed. In the following, this kit will be called Kit V. In late March a second kit (Kit $\mathrm{H}$ ) was received from the National Research Council. In the determination of the density with this kit, a vertical snow face was cut down to the surface of the earth, and samples of $250 \mathrm{~cm} .{ }^{3}$ (later $500 \mathrm{~cm} \cdot{ }^{3}$ ) were obtained by inserting cylinders horizontally at regular intervals into the snow face.

On 3 April observations were taken at the same place with both kits. Kit $\mathrm{V}$ gave a mean censity of $0.300 \mathrm{~g} . \mathrm{cm} .^{-3}$ for $30 \mathrm{~cm}$. of snow. With Kit $\mathrm{H}$ samples of $250 \mathrm{~cm} .{ }^{3}$ were taken at 4 , I I, I9 and $26 \mathrm{~cm}$. from the earth's surface, weighing respectively $90,89,8 \mathrm{I}$ and $72 \mathrm{~g}$. The mean density was $0.332 \mathrm{~g}$. $\mathrm{cm} .^{-3}$. This process was repeated on a number of occasions, giving the pairs of values in Table II.

Table II. Mean Density of the Snow Cover as Computed by Horizontal. and Vertical SAMPLING OF THE SNOW

\begin{tabular}{|c|c|c|}
\hline \multirow[t]{2}{*}{ Date } & \multicolumn{2}{|c|}{$\begin{array}{l}\text { Mean density } \\
\left(\mathrm{g} . \mathrm{cm} \cdot{ }^{-3}\right)\end{array}$} \\
\hline & By Kit $H$ & By Kit $V$ \\
\hline 29 March & $0 \cdot 32$ & 0.27 \\
\hline 3 April & 0.30 & 0.29 \\
\hline 3 April & 0.33 & $0 \cdot 30$ \\
\hline 8 April & 0.33 & $0.3 \mathrm{I}$ \\
\hline I4 April & $0.3 \mathrm{I}$ & 0.29 \\
\hline 21 April & $0 \cdot 33$ & $0.3^{0}$ \\
\hline 27 April & 0.34 & 0.27 \\
\hline 4 May & 0.32 & 0.29 \\
\hline 8 May & $0.3 \mathrm{I}$ & $0 \cdot 25$ \\
\hline I I May & $0 \cdot 30$ & \\
\hline I4 May & 0.29 & $0 \cdot 30$ \\
\hline 18 May & 0.31 & $0 \cdot 3 \mathrm{I}$ \\
\hline 25 May & 0.30 & $0 \cdot 32$ \\
\hline 29 May & 0.35 & $0 \cdot 36$ \\
\hline 1 June & 0.30 & $0 \cdot 33$ \\
\hline 8 June & 0.37 & $0 \cdot 37$ \\
\hline
\end{tabular}

According to the data given in Table II, the two methods of obtaining the density of snow failed to give consistently the same values correct to two significant figures. This was true even when extreme care was taken with assistance from others to ensure that no snow was lost from the bottom of the vertical sample, and that all measurements and weights were determined accurately. No evidence can be produced to justify one method as better than the other. But after consideration, the author concluded that the vertical sampler gives the more reliable value. When the density of the snow varies from layer to layer, with layers at times less than 3 in. $(7 \cdot 62 \mathrm{~cm}$.) thick, the weight of a horizontal sample is very sensitive to the position of the center of the sample relative to the layers of snow.

When one combines the data of Table II with the conclusions based on curve (b) in Figure I, one wonders whether there is value in attempting to obtain the density of the snow 
layer in the Arctic to any accuracy greater than $\pm 0 \cdot 05 \mathrm{~g} . \mathrm{cm} .^{-3}$. The variability of the density from layer to layer and from place to place even when the locations are close together suggests that extreme accuracy for a specific location is not warranted.

\section{Conclusion}

The series of observations on the depth of snow at 2I sites near the Resolute weather station confirms what is already known, that the recorded depths of newly fallen snow cannot be considered too reliable. The series also suggests that the choice of a representative site or a number of sites, from which a mean snow depth can be determined, is difficult. Also, the variation in snow density both in the vertical and over a small area is such that observed values should be considered accurate only within the range of $\pm 0 \cdot 05 \mathrm{~g} . \mathrm{cm} .{ }^{3}$.

\section{Acknowledgements}

The author wishes to acknowledge with thanks the interest of Mr. L. W. Gold, of the National Research Council, Ottawa, Ontario, in the data and his help in its analysis, and also the cooperation and suggestions of Mr. S. W. Dewar, of the Dominion Public Weather Office, Edmonton, Alberta, in the preparation of the manuscript.

MS. received 5 April 1960 